\title{
Periodontal and prosthetic treatment in cases of iatrogenic biological width violation - case report
}

\author{
Skojarzone leczenie periodontologiczno-protetyczne w przypadku \\ jatrogennego naruszenia szerokości biologicznej - opis przypadku
}

\author{
Mariusz Cierech ${ }^{1}$, Kamila Sapielak ${ }^{2}$, Elżbieta Wojtyńska ${ }^{1}$, \\ Bohdan Baczkowski', Kristina Kovalenko ${ }^{2}$, Jarostaw Krajewski ${ }^{2}$, \\ Elżbieta Mierzwińska-Nastalska ${ }^{1}$
}

\footnotetext{
${ }^{1}$ Katedra Protetyki Stomatologicznej, Warszawski Uniwersytet Medyczny

Chair of Prosthodontics, Medical University of Warsaw

Kierownik: prof. dr hab. n. med. Elizbieta Mierzwińska-Nastalska

2 Centrum Medyczne Warszawskiego Uniwersytetu Medycznego

Medical Centre of Medical University of Warsaw

Kierownik: dr n. med. Ewa Trzepla
}

\section{KEY WORDS:}

biological width, interdisciplinary treatment, pink aesthetics, clinical crown lengthening

\section{Summary}

Modern dentistry is based on a comprehensive approach to treatment. In order to achieve a satisfactory functional and aesthetic effect, interdisciplinary care involving several specialists is often required. The article presents the periodontal and prosthetic treatment of a 48-year-old patient, in whom previously made prosthetic restorations compromised the biological width and led to recurrent gingivitis. Due to the complexity of the issue, interdisciplinary multi-stage treatment was necessary. Thus a simple and predictable way to reconstruct proper relations within the dento-gingival complex using a specially designed surgical template is presented. The achieved aesthetic effect fully satisfied both the patient and the dental team.

\section{HASŁA INDEKSOWE:}

szerokość biologiczna, leczenie interdyscyplinarne, różowa estetyka, wydłużenie korony klinicznej zęba

\section{Streszczenie}

Wspótczesna stomatologia opiera się na kompleksowym podejściu do leczenia. Aby uzyskać zadowalajacy efekt funkcjonalny $i$ estetyczny często konieczna jest interdyscyplinarna opieka lekarzy wielu specjalności. $W$ artykule przedstawiono leczenie periodontologiczno - protetyczne 48-letniej pacjentki, u której wykonane uzupetnienia protetyczne zaburzyly szerokość biologiczna $i$ doprowadzity do nawracających stanów zapalnych przyzębia. Ze względu na złożoność problemów konieczne było interdyscyplinarne leczenie wieloetapowe. Zaprezentowano prosty i przewidywalny sposób na odtworzenie prawidlowych stosunków w obrębie zespolu zębowo - dziąstowego przy użyciu specjalnie zaprojektowanego do tego celu szablonu chirurgicznego. Efekt estetyczny w petni zadowalat zarówno zespół lekarzy, jak $i$ sama pacjentkę. 


\section{Background}

The determinant of success in prosthetic treatment, in addition to restoring the function, is the aesthetic effect that should fully satisfy the patient as well as the dentist. It depends on the position, shape and colour of the teeth in the aesthetic area, but also on the "pink aesthetics" and the position of the gums while smiling. In the study concerning the aesthetics of prosthetic treatment, Ahmad $^{1}$ lists four components: the composition of the face with respect to the nasolabial angle and the Ricketts plane, the dento-facial composition relating to the static and dynamic relationship of teeth and lips, the dental composition based mainly on the golden proportion, and the gingival composition, which is the subject of this publication. The term "gingival aesthetic line" (GAL) is understood as the line connecting the most apical and distal gingival marginal points of the central incisors and canines. ${ }^{2}$ The central point of the marginal gingival margin of the lateral incisor may have a different position relative to the GAL line. The standard is a position in the range of 1-2 $\mathrm{mm}$ below or above this line. The position of the GAL line in relation to the upper lip line in the maximum smile should reach up to 3 $\mathrm{mm}$ (Majewski ${ }^{3}$ reports a range of $2-4 \mathrm{~mm}$ ), otherwise it is called a gummy smile. When planning prosthetic treatment with permanent restorations, the dento-gingival complex and the biological width are of key importance. The dento-gingival complex is the area between the gingival margin and the edge of the alveolar ridge, including the gingival sulcus, the junctional epithelium and the connective tissue attachment. Biological width is the space created by the epithelial and connective tissue that is an attachment of soft tissues to the surface of the tooth. In healthy periodontium, the biological width is about $2.5 \mathrm{~mm}$. In turn, the dento-gingival complex is about $3 \mathrm{~mm}$ on the labial surface up to $4-4.5 \mathrm{~mm}$ or even up

\section{Wstęp}

Wyznacznikiem powodzenia w leczeniu protetycznym poza przywróceniem funkcji jest osiągnięty efekt estetyczny, który w pełni powinien satysfakcjonować pacjenta, jak i lekarza stomatologa. Zależy on od ustawienia, kształtu i koloru zębów w strefie estetycznej, aczkolwiek ważna jest również „estetyka różowa” i pozycja dziąseł podczas uśmiechu. Ahmad ${ }^{1}$ w swojej publikacji dotyczącej estetyki leczenia protetycznego wymienia 4 składowe: kompozycję twarzy $\mathrm{w}$ odniesieniu między innymi do kąta nosowo-wargowego oraz płaszczyzny Rickettsa, kompozycję zębowo-twarzową odnoszącą się do wzajemnej statycznej i dynamicznej relacji zębów i warg, kompozycję zębową opartą w głównej mierze na zasadzie złotej proporcji oraz kompozycję dziąsłową, która jest przedmiotem niniejszej publikacji. Pod pojęciem dziąsłowej linii estetycznej GAL (gingival aesthetic line) rozumie się linię łączącą najbardziej dowierzchołkowo i dystalnie położone punkty dziąsła brzeżnego zębów siecznych przyśrodkowych i kłów. ${ }^{2}$ Centralny punkt dowierzchołkowo położonego dziąsła brzeżnego siecznego zęba bocznego może mieć różne położenie w stosunku do linii GAL. Za normę uznaje się położenie w zakresie 1-2 mm poniżej lub powyżej tej linii. Samo umiejscowienie linii GAL w stosunku do położenia linii wargi górnej w maksymalnym uśmiechu powinno wynosić do $3 \mathrm{~mm}$ (Majewski ${ }^{3}$ podaje zakres 2-4 $\mathrm{mm}$ ), w przeciwnym razie mówi się o uśmiechu dziąsłowym (gummy smile).

W przypadku planowania leczenia protetycznego z zastosowaniem uzupełnień stałych kluczowe znaczenie ma zespół zębowo-dziąsłowy i szerokość biologiczna. Zespół zębowo-dziąsłowy to obszar pomiędzy brzegiem dziąsła, a brzegiem kości wyrostka zębodołowego obejmujący szczelinę dziąsłową, przyczep nabłonkowy i przyczep łącznotkankowy. Szerokość biologiczna to przestrzeń utworzona 
to $5.25 \mathrm{~mm}$ on the interdental surface - it is the height of the interdental papilla from the alveolar ridge. ${ }^{4}$

The concept of biological width was used for the first time by Ingber ${ }^{5}$ in 1977 . He defined the width of the connective tissue attachment in the range of $0.29-1.8 \mathrm{~mm}$ (mean $1.07 \mathrm{~mm}$ ), epithelial junction $0.32-3.27 \mathrm{~mm}$ (mean 0.97 $\mathrm{mm}$ ) and the gingival sulcus $0.26-6.03 \mathrm{~mm}$ (average $0.69 \mathrm{~mm}$ ). The biological width, which is the protective zone of the periodontal and alveolar ridge, $, 6,7$ is a constant value in a given case. Its violation may result in persistent gingival inflammation in the case of thick biotype, or progressive recession in the case of thin biotype. ${ }^{1}$ This results in important clinical implications that allow the edge of the prosthetic crown to be positioned $0.5 \mathrm{~mm}$ apically to the depth of the gingival sulcus or 2-3 mm up to the edge of the alveolar bone. ${ }^{1}$ For the positioning of the edge of the crown, bone and gum thickness (biotype) is also important. ${ }^{8}$ Changes in periodontium caused by iatrogenic action require new prosthetic restorations which respect to the biological width. $., 7,9$

\section{Case report}

A 48-year-old woman, concerned about the condition of her gingivae, presented for a checkup at the Medical Centre of Medical University of Warsaw. The patient reported difficulties in oral care, problems with bleeding on brushing and recurrent inflammation around prosthetic restorations in the anterior segment of the maxilla (Fig. 1). The restorations had been placed less than two years earlier. Medical history was irrelevant. The intra-oral examination revealed the following problems. Firstly, some teeth missing, which corresponded to Class IV in the maxilla and Class II in the mandible (according to Galasińska-Landsbergerowa classification). Secondly, abnormal occlusal plane and pathological abrasion of lower teeth were przez przyczep nabłonkowy i łącznotkankowy stanowiący połączenie tkanek miękkich z powierzchnią zęba. W zdrowym przyzębiu biologiczna szerokość tkanek miękkich wynosi około 2,5 mm. Z kolei zespół zębowo-dziąsłowy to około $3 \mathrm{~mm}$ na powierzchni wargowej do 4-4,5 $\mathrm{mm}$ lub nawet do 5,25 $\mathrm{mm}$ na powierzchni stycznej - jest to wysokość brodawki od podstawy kostnej. ${ }^{4}$

Pojęcie szerokości biologicznej zostało po raz pierwszy użyte przez Ingbera ${ }^{5}$ w 1977 roku. Określił on szerokość przyczepu łącznotkankowego w zakresie 0,29-1,8 (śr. 1,07 $\mathrm{mm}$ ), przyczepu nabłonkowego 0,32-3,27 (śr. $0,97 \mathrm{~mm}$ ) oraz szczeliny dziąsłowej 0,26-6,03 (śr. 0,69 mm). Szerokość biologiczna, która stanowi strefę ochronną ozębnej i szczytu kości wyrostka zębodołowego, ${ }^{6,7}$ jest $\mathrm{w}$ danym przypadku wartością stałą i naruszenie jej może skutkować utrzymującym się stanem zapalnym dziąsła brzeżnego w przypadku grubego biotypu lub postępującą recesją w przypadku biotypu cienkiego. ${ }^{1}$ Wynikają $\mathrm{z}$ tego ważne implikacje kliniczne pozwalające umiejscowić brzeg korony protetycznej $0,5 \mathrm{~mm}$ dowierzchołkowo w głąb szczeliny dziąsłowej lub 2-3 mm dokoronowo od brzegu kości wyrostka zębodołowego. ${ }^{1}$ Dla położenia brzegu korony oprócz wysokości wyrostka istotna jest grubość kości i dziąsła (biotyp). ${ }^{8}$ Zmiany w przyzębiu wywołane jatrogennym działaniem wymagają wykonania nowych uzupełnień protetycznych z zachowaniem szerokości biologicznej. 6,7,9

\section{Opis przypadku}

Do Poradni Periodontologii Centrum Medycznego WUM zgłosiła się 48-letnia kobieta zaniepokojona stanem swoich dziąseł. $\mathrm{W}$ wywiadzie pacjentka podała trudności $\mathrm{w}$ utrzymaniu należytej higieny, krwawienie przy szczotkowaniu oraz nawracające stany zapalne w obrębie stałych uzupełnień protetycznych w szczęce w odcinku przednim (ryc. 1). 


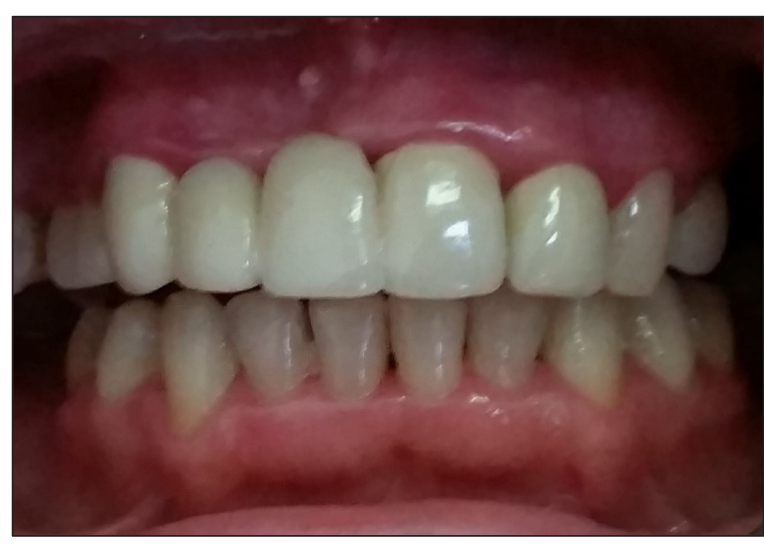

Fig 1. Intraoral picture - condition before treatment. Ryc. 1. Zdjęcie wewnątrzustne - stan przed leczeniem.

observed. The patient had a porcelain-fusedto-metal bridge 15-13--21, a porcelain-fusedto-metal crown on tooth 22 and (cantilever) bridge 24-. The prosthetic restorations had incorrect profile, the pontic was located too close to the alveolar ridge and the interdental papillae were not unburdened, which made oral care problematic. The construction of the cantilever bridge increased mobility of tooth 24 and impacted vertical bone loss. Periodontal probing revealed increased pocket depths at most abutments. The patient was referred to have an OPG taken (Fig. 2) and periapical radiographs of teeth $15-24$. Basing on clinical and radiographic examinations it was established that prosthetic restorations had been responsible for the disruption of the biological width and in view of the thick biotype the cause of chronic periodontitis. It was decided to undertake multidisciplinary treatment involving periodontics and prosthetics.

Following periodontal non-surgical treatment, pocket depths re-evaluation was performed. The examination revealed hardly any improvement. As the first stage of perioprosthetic treatment it was decided to cut off the pontic of tooth 25 from the bridge in order to improve its biomechanical properties. Due to the lower front teeth abrasion it was decided to utilize an NTI plate for four weeks

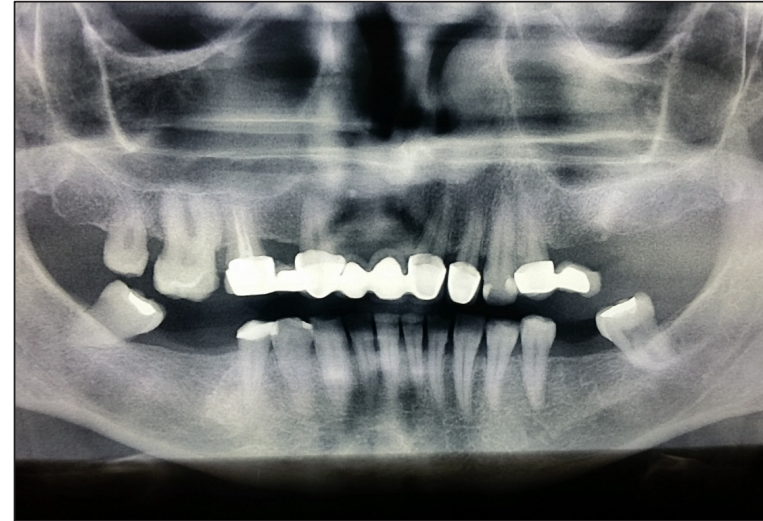

Fig. 2. Orthopantomogram-prior to treatment. Ryc. 2. Zdjęcie pantomograficzne przed rozpoczęciem leczenia.

Uzupełnienia były wykonane około 2 lata temu. Wywiad ogólnomedyczny bez istotnego znaczenia. W badaniu klinicznym stwierdzono braki zębowe klasy IV w szczęce oraz klasy II w żuchwie w klasyfikacji GalasińskiejLandsbergerowej, zaburzenia płaszczyzny zwarcia oraz starcie patologiczne w obrębie zębów dolnych przednich. Pacjentka użytkowała most lany licowany porcelaną 15-13- 21 , koronę laną licowaną porcelaną 22 oraz most jednobrzeżny 24- . Wykonane uzupełnienia posiadały nieprawidłowy profil wyłaniania, a ukształtowanie przęsła polegające na zbyt mocnym przyleganiu do wyrostka zębodołowego i brakiem odciążenia brodawek uniemożliwiało należytą higienę. Konstrukcja mostu jednobrzeżnego 24- spowodowała zwiększoną ruchomość zęba 24 oraz ubytek pionowy kości. Po przeprowadzeniu sondowania kieszonek dziąsłowych (PD), stwierdzono zwiększoną głębokość przy większości zębów filarowych. Pacjentkę skierowano na zdjęcie pantomograficzne (ryc. 2) oraz zdjęcia zębowe 15 - 24. Na podstawie badania klinicznego i zdjęć radiologicznych stwierdzono, iż uzupełnienia protetyczne zaburzają szerokość biologiczną, a przy grubym biotypie dziąsła są przyczyną nawracających stanów zapalnych przyzębia brzeżnego. Zdecydowano o podjęciu skojarzonego leczenia periodontologiczno-protetycznego. 


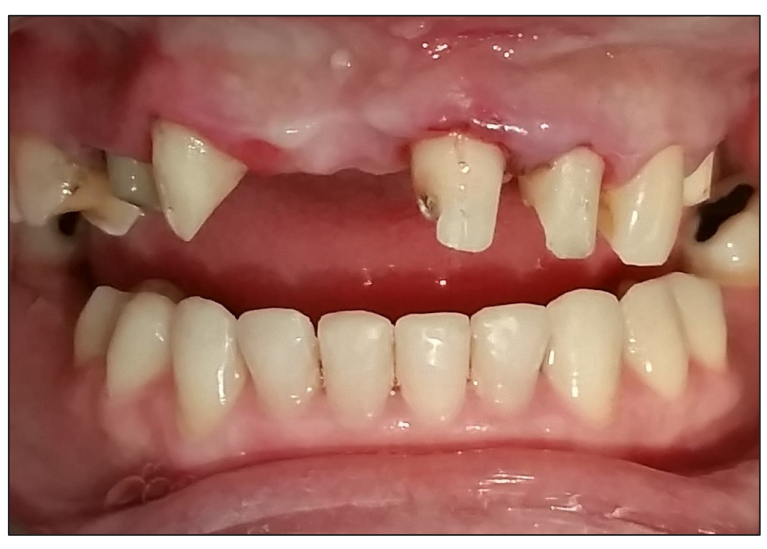

Fig. 3. Intraoral picture-after removing prosthetic appliances in the upper arch.

Ryc. 3. Zdjęcie wewnątrzustne po zdjęciu uzupetnień protetycznych w tuku górnym.

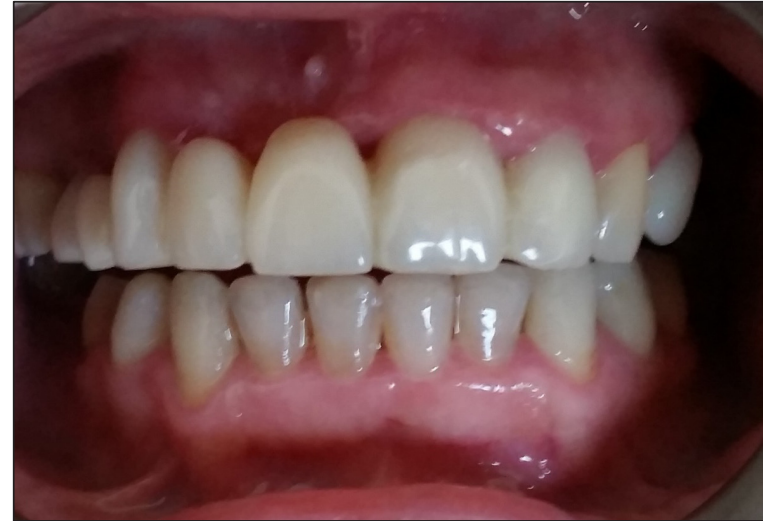

Fig. 4. Temporary restorations with proper teeth, pontics and interdental spaces design facilitating optimal hygiene.

Ryc. 4. Wykonane uzupelnienia tymczasowe z prawidlowym profilem wylaniania, prawidlowym uksztattowaniem przęsel oraz przestrzeni międzyzębowych umożliwiających optymalna higienę.

Po zakończonej fazie niechirurgicznego leczenia periodontologicznego ponownie zbadano głębokość kieszonek dziąsłowych uzyskując niewielką poprawę. W pierwszej kolejności zdecydowano o odcięciu przęsła 25 poprawiając biomechanikę konstrukcji. Ze względu na starcie zębów w odcinku przednim żuchwy zdecydowano o deprogramacji pacjentki przy użyciu płytki NTI przez okres 4 tygodni. Po okresie deprogramacji stwierdzono, iż zwarcie nawykowe znajduje się w obrębie relacji centralnej. Za pomocą materiału złożonego wyrównano płaszczyznę zwarcia w łuku dolnym i następnie usunięto wszystkie uzupełnienia protetyczne w obrębie łuku górnego, stwierdzając próchnicę filaru 21 oraz zaburzenia braku symetrii w obrębie linii dziąsłowej (ryc. 3). Zdecydowano o rewizji leczenia endodontycznego zęba 15 oraz wykonaniu wkładu k-k z włókna szklanego w celu uzyskania prawidłowej retencji dla przyszłej korony. W laboratorium protetycznym wykonano uzupełnienia tymczasowe z prawidłowym profilem wyłaniania oraz ukształtowaniem przęseł i przestrzeni międzyzębowych umożliwiających optymalną higienę (ryc. 4). Następnie zaplanowano 


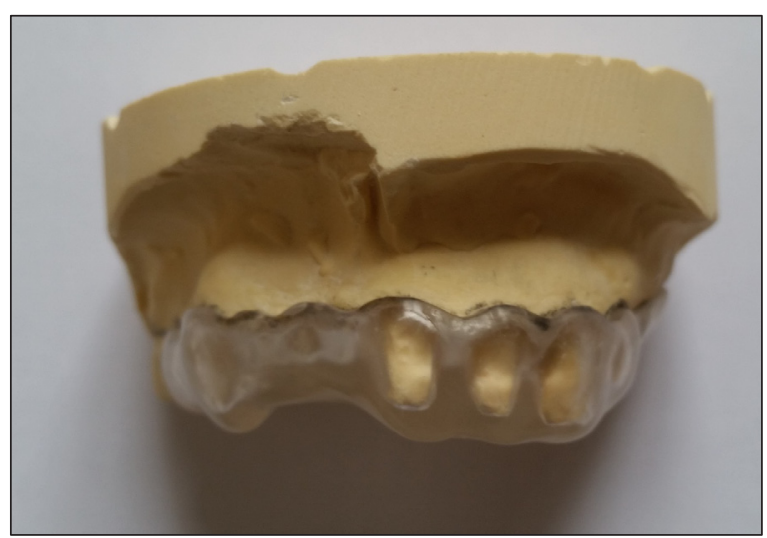

Fig. 5. Self-cured acrylic resin surgical template. Ryc. 5. Szablon chirurgiczny wykonany z polimeryzowanego chemicznie tworzywa akrylowego.

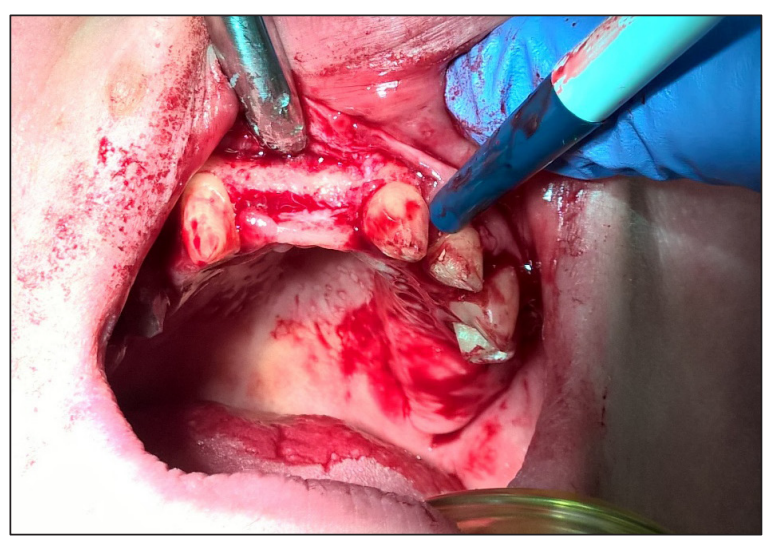

Fig. 7. Intra-operative picture after mucoperiosteal flap reflection.

Ryc. 7. Zdjęcie śródzabiegowe po odwarstwieniu płata śluzówkowo-okostnowego.

line was parallel to the interpupillary line and symmetrical in relation to the midline.

Clinical crown lengthening was carried out in local anaesthesia. The intrasulcular incision was made and the flap was reflected (Fig. 7). Osteotomy and osteoplasty on vestibular and approximal surfaces of teeth were done. Through root surface debridement was performed. The obtained result was comapered with the surgical template. With a periodontal probe the distance between the margin of the alveolar bone and the edge of the template the future margin of the prosthetic restorationwas checked (Fig. 8). The flap was repositioned and closed using a 4-0 suture, to be removed

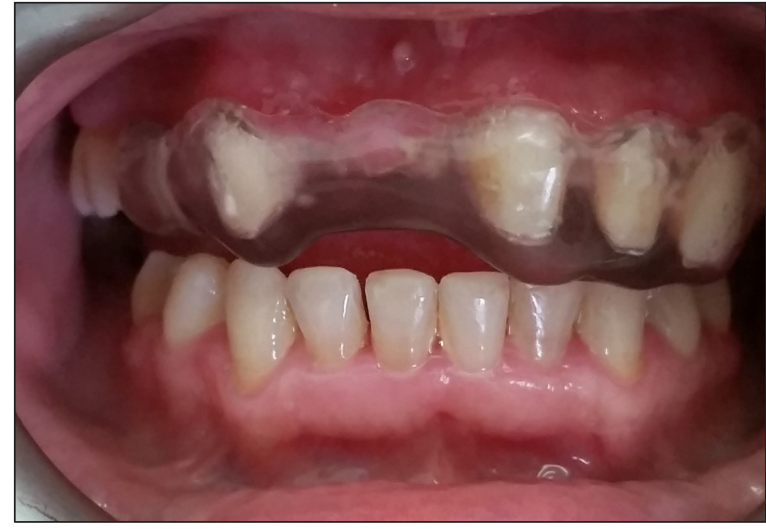

Fig. 6. Intraoral surgical template control. Ryc. 6. Kontrola szablonu chirurgicznego w ustach pacjentki.

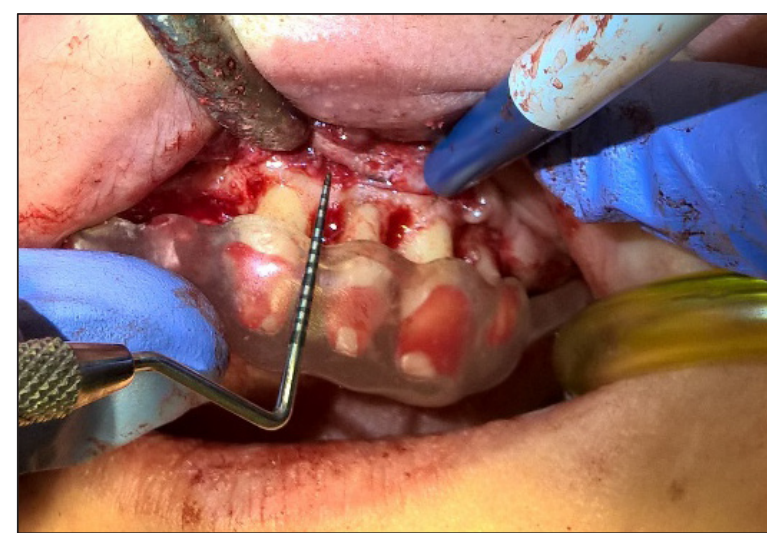

Fig. 8. Intra-procedural surgical template control. Ryc. 8. Kontrola śródzabiegowa z szablonem chirurgicznym.

zabieg wydłużenia koron klinicznych z zamiarem przywrócenia prawidłowej szerokości biologicznej oraz poprawy symetrii i położenia estetycznej linii dziąsłowej (GAL). Po zdjęciu uzupełnień tymczasowych wykonano wycisk, z którego odlano model gipsowy w celu zaprojektowania szablonu chirurgicznego z zaznaczeniem optymalnego pod względem czynnościowym i estetycznym konturu dziąsłowego. Szablon wykonano z polimeryzowanego chemicznie bezbarwnego tworzywa akrylowego (ryc. 5) i skontrolowano w ustach pacjentki (ryc. 6). Oceniono równoległość położenia linii GAL w stosunku do linii źrenic oraz jej symetrię według linii pośrodkowej. 


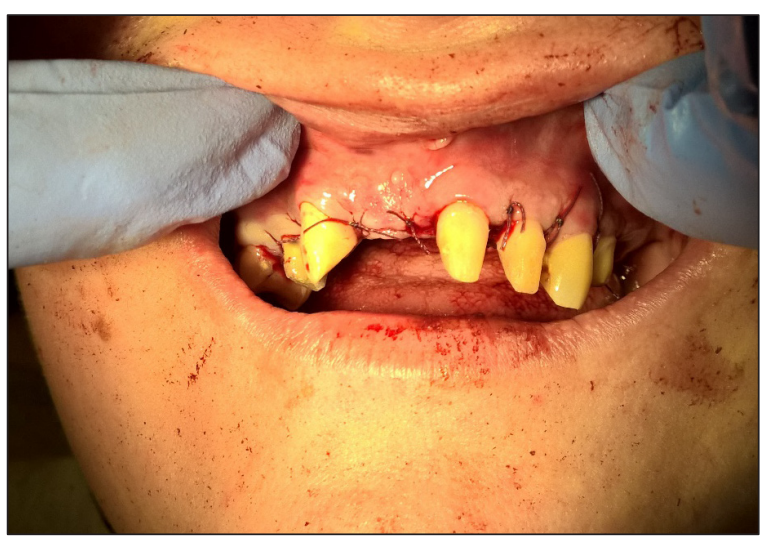

Fig. 9. Situation immediately after surgical treatment.

Ryc. 9. Stan bezpośrednio po zakończeniu zabiegu chirurgicznego.

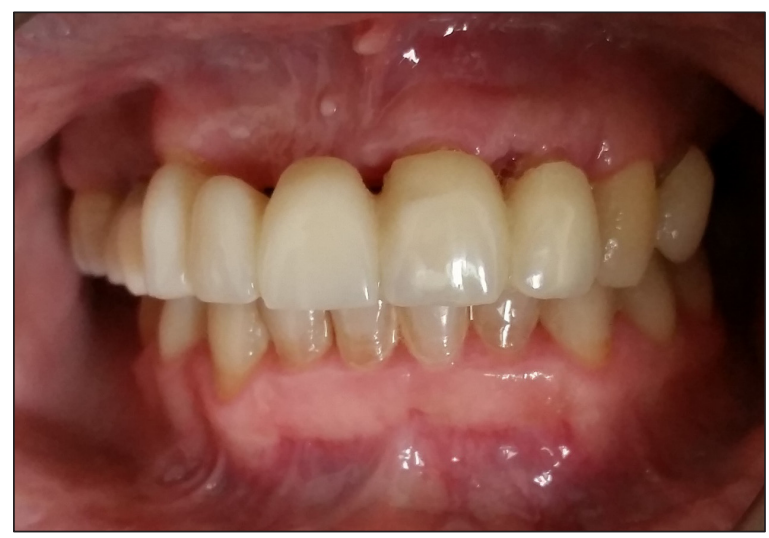

Fig. 11. Situation attwo weeks after surgery; satisfactory gingiva condition with visible spaces between temporary pontics and the gingival margin.

Ryc. 11. Stan 2 tygodnie po zabiegu; stan dziasta brzeżngo prawidlowy $z$ widocznymi przestrzeniami pomiędzy przestem tymczasowych uzupelnień protetycznych a błona śluzową.

after 14 days (Fig. 9, 10). After two weeks the marginal gingiva healed, but there was a visible space between the pontic of the temporary bridge and the mucous membrane, which was problematic for the patient both aesthetically and phonetically (Fig. 11). In addition, due to root exposure the patient reported slight teeth hypersensitivity to exogenous influences. Abutments were reshaped placing the chamfer-shapal margin gingivally. A new temporary restoration was made awaiting complete healing of the soft tissues (Fig. 12).

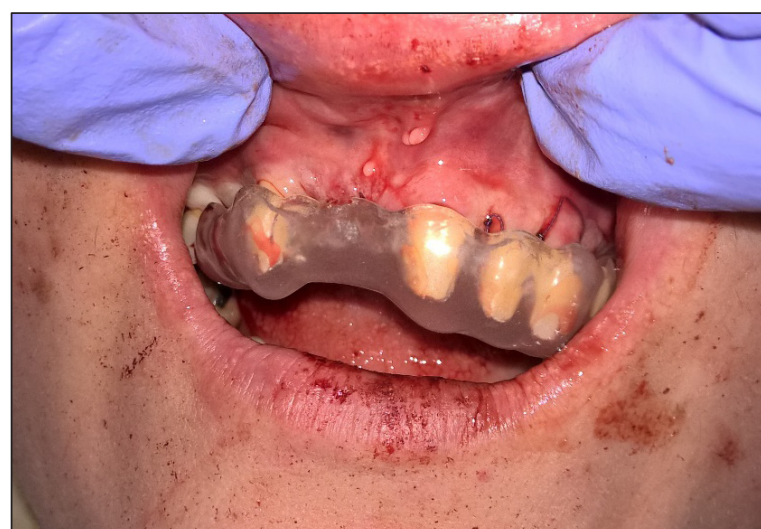

Fig. 10. Intraoral surgical template control. Ryc. 10. Kontrola wewnatrzustna $z$ szablonem chirurgicznym.

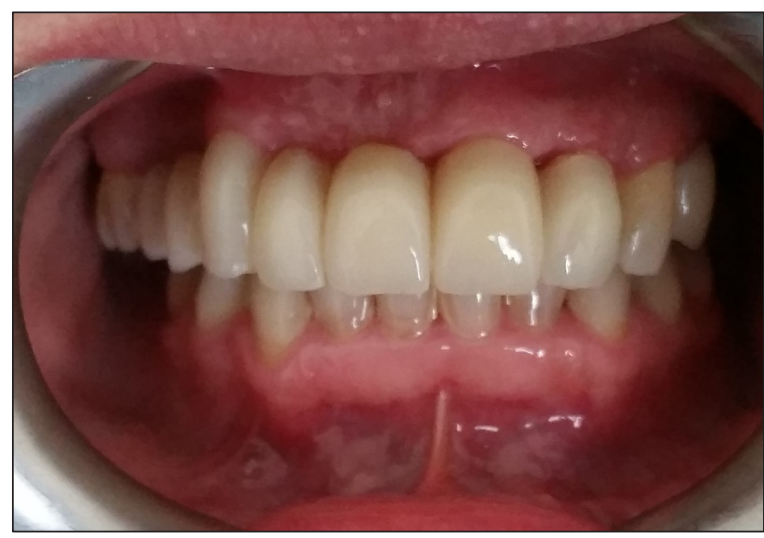

Fig. 12. New temporary restorations re-establishing satisfactory aesthetic result.

Ryc. 12. Nowe uzupelnienia tymczasowe przywracające zadowalający efekt estetyczny.

Zabieg wydłużenia koron klinicznych przeprowadzono w znieczuleniu miejscowym. Cięcie wykonano przez szczelinę dziąsłową, odwarstwiono płat pełnej grubości (ryc. 7), wykonano osteotomię i osteoplastykę kości od strony przedsionkowej, powierzchni stycznych oraz oczyszczono powierzchnie korzeni. Sprawdzono uzyskany efekt z szablonem chirurgicznym. Przy pomocy sondy periodontologicznej skontrolowano odległość brzegu kości wyrostka zębodołowego do brzegu szablo$\mathrm{nu}$ - przyszłej granicy odbudowy protetycznej 
At two months postoperatively, pocket depths were re-evaluated and proper PD values of $1-3 \mathrm{~mm}$ were obtained. The achieved aesthetic effect was fully satisfactory both for the patient and the dental team. The next stage of the procedure will involve replacement of the temporary restorations in the maxilla with permanent restorations.

\section{Conclusions}

This publication presents the protocol of conducting the combined periodontal and prosthetic treatment. It is a simple and predictable method for re-establishing proper relations within the dento-gingival complex. (ryc. 8). Płat zreponowano i założono szwy 4.0 na 14 dni (ryc. 9 i 10). Po okresie 2 tygodni od zabiegu, doszło do wygojenia dziąsła brzeżnego z widocznymi przestrzeniami pomiędzy przęsłem tymczasowych uzupełnień protetycznych a błoną śluzową, które przeszkadzały pacjentce zarówno pod względem fonetycznym, jak i estetycznym (ryc. 11). Dodatkowo ze względu na odsłonięcie korzeni pacjentka podawała niewielką nadwrażliwość na czynniki zewnętrzne. Dokonano korekty opracowania filarów umiejscawiając stopień w położeniu dodziąsłowym i wykonano nowe uzupełnienia tymczasowe w laboratorium oczekując na pełne wygojenie tkanek miękkich (ryc. 12). Po dwóch miesiącach od zabiegu dokonano pomiaru głębokości kieszonek dziąsłowych uzyskano wartości prawidłowe (1-3 mm). Efekt estetyczny w pełni zadowalał zarówno zespół lekarzy, jak i samą pacjentkę. W kolejnym etapie tymczasowe uzupełnienia protetyczne zostaną w szczęce zastąpione konstrukcją długoczasową.

\section{Podsumowanie}

Istotą niniejszej publikacji jest przedstawienie protokołu postępowania skojarzonego leczenia periodontologiczno-protetycznego, który w sposób prosty i przewidywalny pozwala na odtworzenie prawidłowych stosunków w obrębie zespołu zębowo-dziąsłowego.

\section{References / Piśmiennictwo}

1. Ahmad I: Stomatologia estetyczna, Elsevier Urban \& Partner 2007: 21-50.

2. Ahmad I: Anterior dental aesthetics: Gingival perspective. British Dent J 2005; 4: 195-202.

3. Majewski S: Współczesna protetyka stomatologiczna. Podstawy teoretyczne i praktyka kliniczna, Elsevier Urban \& Partner 2014.
4. Pietruska M, Pietruski J: Periodontologicznoimplantologiczna chirurgia plastyczna, Czelej 2014.

5. Ingber JS, Rose LF, Coslet JG: The „biologic width" - a concept in periodontics and restorative dentistry. Alpha Omeg 1977; 70: 62-65. 
6. Trąbsk-Świtelnicka M, Dembowska E, Samulak-Zielińska $R$ : Implikacje kliniczne naruszenia szerokości biologicznej przyzębia. Mag Stom 2012;1: 30-33.

7. Kwiecień $K$ : Uzupełnienia protetyczne $\mathrm{w}$ aspekcie chorób przyzębia - przegląd piśmiennictwa. Med Trib Stom 2018; 7-8: 3136.

8. Wolf HF, Rateitschak EM, Rateitschak KH:
Perodontologia, Czelej 2006.

9. Romaniuk-Demonchaux A: Szerokość biologiczna przyzębia rozpatrywana $\mathrm{w}$ aspekcie lokalizacji brzegu stałych uzupełnień protetycznych. Twój Przeg Stom 2017; 1-2: 44-51.

Zaakceptowano do druku: $11.10 .2018 \mathrm{r}$.

Adres autorów: 02-006 Warszawa, ul. Nowogrodzka 59.

C Zarząd Główny PTS 2018. 